tros elementos adextrados nas escolas que atualmente servem naquela importante organização.

Com o Ensino Profissional despendia o Estado, em 1941, Cr\$ 9.394.540,00. No corrente ano, essa cifra eleva-se a $\mathrm{Cr} \$$ $14.640 .845,70$.

Colônias de Ferias, Parques Infantis, Escolas de Aplicação ao Ar Livre - $\mathrm{O}$ serviço de Colônias de Férias passou por um impulso apreciável com atividades das mais auspiciosas.

Assim é que além da Colônia Marítima Infantil " Álvaro Guião ", em Santos, que foi reaberta, instalou-se a Colônia Vale do Paraíba, em Pindamonhan-gaba. Também foi localizada pelo Departamento de Educação Física em Campos do Jordão, a Colônia da Serra da Mantiqueira. Os parques infantis atravessam uma fase promissora. Sob a orientação do Departamento de Educação Física, já se encontram instalados 4 parques no interior c outros muitos estarão em condições de funcionar dentro em breve, mantidos pelas Prefeituras.

Mantém o Departamento de Educação Física, com excelentes resultados, escolas de aplicação ao ar livre, nas quais, além do ensino pré-primário e primário, é ministrada educação física às crianças, por professoras especializadas; cen- tro de educação física instalado nas dependências do Estádio Municipal do Pacaembu, que vem proporcionando ao público, a prática racional da educação física com a assistência permanente de médicos e de instrutores especializados.

Desde 1941, o Departamento de Educação Física passou a inspecionar e orientar a prática da educação física em todos os estabelecimentos de ensino secundário e normal oficiais. Nos grupos escolares, é ministrado o ensino de educação física às crianças, por intermédio de competentes professoras, cujos serviços já se vão estendendo-se às cidades do interior.

Como se vê, o Governo do Estado vem cuidando com especial interesse, da educação física das nossas crianças e jovens que freqüentam as escolas e, também, dos homens, em geral, bem certo do papel que representa a cultura física na formação do nossa raça".

\section{RIO DE JANEIRO}

O Departamento de Educação iniciou a realização, em caráter experimental, de " missões culturais". Várias dessas missões já percorreram os municípios de Maricá, Saquarema, Araruama, São Pedro da Aldeia e Cabo Frio. No mês de julho, trabalho semelhante será feito nos municípios de Itaguaí, Mangaratiba, Angra dos Reis e Parati.

\title{
INFORMAÇÃO DO ESTRANGEIRO
}

\section{ARGENTINA}

Segundo informações do Conselho Nacional de Educação da República Argentina, cuja população é de 13 milhões de habitantes, estavam matriculados nesse país no ano passado em escolas públicas e particulares 2.005.731 alunos primários, que correspondem a $15,42 \%$ do total de habitantes.
Para esses alunos havia 14.060 escolas, com 76.368 professores.

As crianças em idade escolar que recebiam instrução, eram 1.929.818 matriculados em 13.615 escolas, que contavam 73.754 professores. Os adultos que freqüentavam escolas primárias eram 75.913 que dispunham de 445 escolas especiais, com 2.614 professores. 
Em Buenos Aires, com 2.300.000 ha bitantes, funcionaram 189 escolas primá rias, com 302.872 alunos e 13.709 proíesores.

Reabriram-se na Escola Normal de Rosário, os cursos de língua portuguesa, a cargo da professora brasileira Maria da Gloria Maia e Almeida, e sob os auspícios do Instituto Argentino-Brasileiro de Cultura.

\section{ESTADOS UNIDOS}

Funcionavam em 1940 nos Estados Unidos, 241.686 estabelecimentos de ensino, assim distribuídos: 223.295 escolas primárias e secundárias públicas; 14.574 escolas primárias e secundárias particulares; 603 instituições públicas e 1.148 instituições particulares de educação superior; 291 internatos públicos e 94 internatos particulares para super-normais, e 1391 escolas de enfermagem. Dos estabelecimentos de ensino primário, 113.600 ainda eram escolas de um só mister.

A matrícula total atinguiu quase 30 milhões de alunos distribuidos assim: 21 milhões nas escolas primárias e jardins de infância; 7.10C.000 nos colégios de ensino secundário; 1.500.000 nas instituições de educação superior; e os restantes nas academias particulares, nas escolas para indígenas e nas escolas de enfermeiras das universidades.

O pessoal docente em todos os níveis de ensino ascendeu a 1.101.983, dos quais 801.078 eram mulheres e 300.905 homens.

A direção imediata do ensino público esteve a cargo de 116.999 unidades administrativas (comissões de educação). A proporção, segundo a qual os diversos órgãos nacionais contribuíram para a manutenção da educação pública, foi a seguinte: Governo Federal 1,7\% ; município $6,7 \%$; distrito $61,3 \%$.

$\mathrm{O}$ custo da educação pública e particular, inclusive inversão de capital, elevou-se a 3.200.000.000 dólares (64 bilhões de cruzeiros) para esse total a instrução privada contribue com $11 \%$.

Em março de 1940 recebiam o benefício do ensino 94,3\% da população de 7 a 9 anos; $95,5 \%$ da população de 10 a 13 anos; $92,5 \%$ da população de 14 anos; $87,6 \%$ da população de 15 anos; 68,7\% da população de 16 e 17 anos. Cerca de $3 / 5(57 \%)$ da população de 5 a 24 anos freqüentavam algum centro de ensino.

De acordo com o recenseamento efetuado em 1940, metade dos habitantes da nação, de 25 anos ou mais, havia oursa-do aproximadamente oito anos e meio de estudos. Por outro lado, $13,7 \%$ do mesmo grupo não tinham adquirido ensino superior ao que se ministram no quinto ano primário.

O nível educacional da população expresso em anos de estudos, foi o seguinte : 3,8\% não haviam cursado um ano sequer de estudos primários; 9,9\% haviam cursado de 1 a 4 anos; $11,6 \%$, de 5 a 6 anos; $35,1 \%$ de 7 a 8 anos; $15,2 \%$ de 1 a 3 anos de estudos secundários; 14,3\%, 4 anos de estudos secundários; 5,5\%, de 1 a 3 anos de, estudos universitários ; 4,6\%, 4 ou mais dos referidos estudos superiores.

\section{URUGUAI}

Os cursos de português e estudos brasileiros, no Instiuto Brasil-Uruguai, em Montevidéu, continuam a ter franco desenvolvimento.

Iniciados em 1941, com 400 alunos, os cursos contém agora com mais de 1.600 alunos. $\mathrm{Na}$ sua direção acha-se o técnico de educação brasileiro, Dr. Albino Peixoto Júnior. 